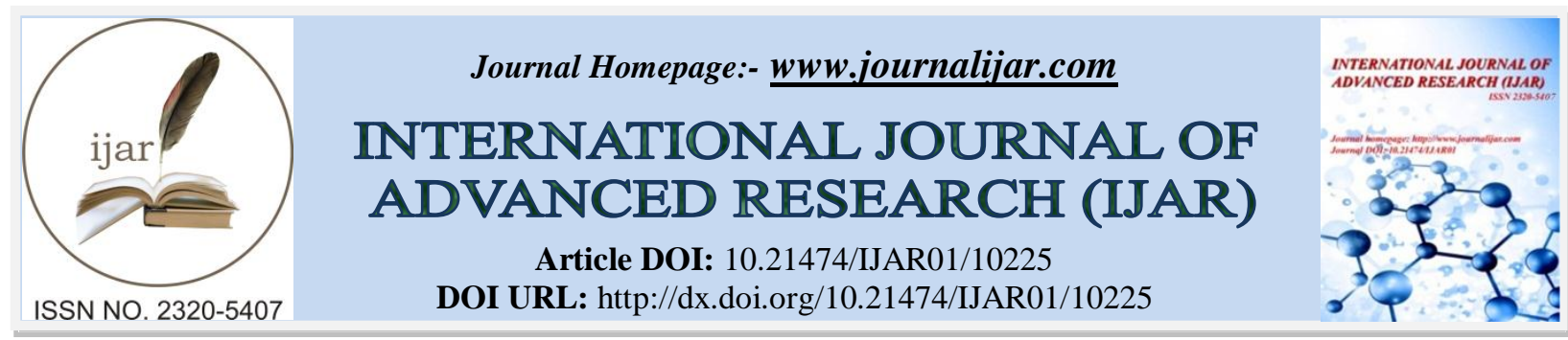

RESEARCH ARTICLE

\title{
RETAIL HOSPITALITY AND SURVIVAL OF THE FITTEST - A STUDY ON UNORGANIZED INDIAN RETAIL SECTOR
}

\section{Vinish P. ${ }^{1}$ and Dr. Maruthi Ram $\mathbf{R}^{2}$}

1. Department of Business Administration, St. Joseph Engineering College, Vamanjoor, Mangaluru - 28.

2. Professor and HOD, BNM Institute of Technology, Banashankari, Bengaluru - 85 .

\section{Manuscript Info}

\section{Manuscript History}

Received: 10 October 2019

Final Accepted: 12 November 2019

Published: December 2019

Keywords:-

Organized, Income, Retail, GDP

\begin{abstract}
Around $70 \%$ of India's population lives in 627000 villages. Retailers both in small and large formats are targeting these untapped markets since rural India has a large consuming class with $41 \%$ of India's middle class and $58 \%$ of the total disposable income. At present, Rural India accounts for $55 \%$ of the total retail market ( $\$ 450$ billion) and it is expected to grow by $\$ 90$ billion in the next 5 years. The organized retailing has grown from 2\% in the year 2000 to 5\% in 2010 and the future growth rate has been estimated at about $35 \%$ per annum. Even though there are plenty of efforts from the government of India in improving the country's GDP through uplifting rural infrastructure through the 5-year plans, no major development has been recorded yet. This is considered to be a major barrier for the entry of large retailers to these markets who are trying to explore new venture to overcome current economic slowdown. Also, the robust presence of Kirana shops and their personal bonding with the rural customers in the neighbourhood villages gives strong competition to these retail giants. This paper attempts to explore the factors supporting the presence and growth of Kirana shops in rural India and consequently analyzing the major challenges in front of the large retailers like HUL and ITC to establish their presence. The paper is conceptual, representing the various facts and information obtained from the online journals, newspaper articles, and surveys by research scholars and various paper publications related to retailing.
\end{abstract}

Copyright, IJAR, 2019, All rights reserved.

\section{Introduction:-}

The Indian retail industry has a history of trade spread over thousands of years with high traditional values attached to it. Remarkably, the tradition is carried forward until the current generation with the help of the country's everpresent Kirana stores. From the time of the Mughal Empire (1526-1757), Kirana stores have been a reliable source of supplies and, still hold a major market share in modern Indian retail. It is projected that by 2021 traditional retail will hold a major share of 75 per cent, organised retail share will reach 18 per cent and e-commerce retail share will reach 7 per cent of the total retail market.

\section{Corresponding Author:- Vinish $\mathbf{P}$}

Address:- Department of Business Administration, St. Joseph Engineering College, Vamanjoor, Mangaluru28. 


\section{The typical Kirana Store:-}

'Kirana' literally means 'grocery', which is what these stores mainly sell. Kirana stores usually function as a family business. A typical Kirana store will range from as little as 25 to 400 square feet in size. They normally hire people from their native place which helps them in creating a warm atmosphere for the customers and create a more productive environment. Also, this helps them in building a strong bond with the family members of the business and neighbouring customers which are carried forward from generations to generations for years together.

\section{The Kirana Touch:-}

Most of the Kirana stores have great neighbourhood locations and supreme access. With ever-increasing traffic congestion, this is a huge customer benefit. Secondly, low - often notional - rents and 'flexible' wage costs often mean the ability to have cost neutrality, if not competitiveness, versus larger players. Indeed, the biggest hurdles that large-format 'modern' retail faces are the high, inflexible rents and the need to constantly train a churning and less flexible staff. Thirdly, since the location of the Kirana stores is in residential areas, most of the Kirana store owners share a close business relationship with their customers which is the major source of outlet loyalty and this, in turn, boost the sales for a longer duration which out much promotional efforts. Since most of the Indians prefer personal interaction during their purchase, Kiranas could considerably dominate organized retail outlets in this regard. Also, many Kiranas nowadays offer free home delivery and follow a monthly based simple credit system which is normally maintained in a notebook.

Kiranas not only deal with grocery items abut also a variety of branded and non-branded products. More often these stores stock items which are low priced and dry food items in order to bring down the cost of cold storage. Because of these reasons the investment in a Kirana store is much lesser compared to a large retail store. As the business progress, they start buying the neighbouring shops which give an appeal of a supermarket.

\section{Rural earnings and spending:-}

According to the provisional data released by Census India, $68.84 \%$ per cent of India's population lives in rural and remaining $31.16 \%$ is urban. Rural India lives on less than Rs 35 a day and nearly as many in cities live on Rs 66 a day, reveals a government survey on income and expenditure. The average per capita daily expenditure comes out to be about Rs 35 in rural and Rs 66 in urban India. About 60 per cent of the population lives with these expenditures or less in rural and urban areas," said Director General of National Sample Survey Organisation (NSSO) J Dash in his preface to the report.

Income generation in rural areas:-

\begin{tabular}{|l|l|l|}
\hline SI No. & Source of income & Proportion of total income (\%) \\
\hline 1 & Agriculture & 58.8 \\
\hline 2 & Agricultural wages & 16.1 \\
\hline 3 & Business and crafts & 8.8 \\
\hline 4 & Non-agricultural wages & 7.2 \\
\hline 5 & Salaries & 2.5 \\
\hline 6 & Current transfers & 1.9 \\
\hline 7 & Others & 4.7 \\
\hline Total & 100 \\
\hline
\end{tabular}

Source: G.M. Pande- Rural Marketing, Thrust and Challenge, p. 30.

Above table indicates that there is no steady source of income since the major source of income is agriculture and is fully dependent on climatic conditions. The salaried class is hardly $2.5 \%$, hence it is very difficult for the organized retailers to do the sales forecasting.

The National Sample Survey Organisation (NSSO) highlights the differences between the rural and urban income and consumption which is a major indicator of rural-urban divide and importantly this helps in understanding the spending pattern of rural customers.

According to the survey, the Key Indicators of Household Consumer Expenditure in India 2009-2010, the average Monthly Per Capita Expenditure (MPCE) in 2009-10 was Rs 1054 in rural India and Rs 1984 in urban India*. 
Which implies per capita expenditure level of the urban population was on an average $88 \%$ higher than the rural counterpart.

Even though the central government claims economic growth in rural markets the above data shows the fiscal divide where 90 per cent of rural India spends less than Rs 68.47 per day per person. Whereas 90 per cent of urban India spend Rs 142.70. Surprisingly, the mounting cost of living in urban areas didn't stop the people in spending much more compared to their counterparts. Now with the falling GDP (currently 5.3\% against 5.7\%), this difference will widen further.

Two years ago, the rural Indian used to spend Rs 55 per day per person and Rs 122 in cities. Taking inflation (of 7.2\%) into consideration the therein not much difference between the spending in the past and present. But the gap between the poorest in villages and the richest in cities has widened further. The poorest 10 per cent in villages spends on an average 15 times less than the top 10 per cent in cities. Even the richest in villages are nowhere near to the upper class in cities.

State Wise per Capita Income Comparison:-

\begin{tabular}{|c|c|c|c|c|}
\hline Sl. No & State/UT & $\begin{array}{l}\begin{array}{l}\text { 2010-11 } \\
\text { (Rupees) }\end{array} \\
\end{array}$ & \begin{tabular}{|l|}
$\begin{array}{l}\text { 2011-12 } \\
\text { (Rupees) }\end{array}$ \\
\end{tabular} & $\begin{array}{l}\text { 2011-12 } \\
\text { Growth }\end{array}$ \\
\hline 1 & Andhra Pradesh & 62912 & 71540 & 13.7 \\
\hline 2 & Arunachal Pradesh & 55789 & 62213 & 11.5 \\
\hline 3 & Assam & 30569 & 33633 & 10 \\
\hline 4 & Bihar & 20708 & 24681 & 19.2 \\
\hline 5 & Jharkhand & 29786 & 31982 & 7.4 \\
\hline 6 & Goa & 168572 & 192652 & 14.3 \\
\hline 7 & Gujarat & 75115 & N. A & N. A \\
\hline 8 & Haryana & 94680 & 109227 & 15.4 \\
\hline 9 & Himachal Pradesh & 65535 & 73608 & 12.3 \\
\hline 10 & Jammu \& Kashmir & 37496 & 41833 & 11.6 \\
\hline 11 & Karnataka & 60946 & 69493 & 14 \\
\hline 12 & Kerala & 71434 & 83725 & 17.2 \\
\hline 13 & Madhya Pradesh & 32222 & N. A & N. A \\
\hline 14 & Chhattisgarh & 41167 & 46573 & 13.1 \\
\hline 15 & Maharashtra & 83471 & N. A & N. A \\
\hline 16 & Manipur & 29684 & 32284 & 8.8 \\
\hline 17 & Meghalaya & 50427 & 56643 & 12.3 \\
\hline 18 & Mizoram & 48591 & N. A & N. A \\
\hline 19 & Nagaland & 52643 & 56116 & 6.6 \\
\hline 20 & Orissa & 40412 & 46150 & 14.2 \\
\hline 21 & Punjab & 69737 & 78171 & 12.1 \\
\hline 22 & Rajasthan & 42434 & N. A & N. A \\
\hline 23 & Sikkim & 81159 & N. A & N. A \\
\hline 24 & Tamil Nadu & 72993 & 84058 & 15.2 \\
\hline 25 & Tripura & 44965 & 50750 & 12.9 \\
\hline 26 & Uttar Pradesh & 26355 & 29417 & 11.6 \\
\hline 27 & Uttarakhand & 66368 & 75604 & 13.9 \\
\hline 28 & West Bengal & 48536 & 55864 & 15.1 \\
\hline 29 & A \& N Islands & 76883 & 82272 & 7 \\
\hline 30 & Chandigarh & 128634 & N. A & N. A \\
\hline 31 & Delhi & 150653 & 175812 & 16.7 \\
\hline 32 & Puducherry & 98719 & 95759 & -3 \\
\hline \multicolumn{5}{|c|}{ All-India Per Capita Net National } \\
\hline \multicolumn{2}{|c|}{ Income (2004-05 base) } & 53331 & 60972 & 14.3 \\
\hline
\end{tabular}

Source: India Business blog. 
According to the above data, India's average Per Capita Income is Rs. 60,972/-, which is one of the lowest in the world.

\section{Haats - "The Rural Supermarkets":}

An illustration of rural spending and brand awareness

Haats is the business centre for the villages. It not only helps the farmers to sell their agricultural produce but also to purchase their daily needs. Around 43000 haats are there in India. Each haat is spread over acres of land and possess 300 to 500 stalls selling everything a villager needs in their daily life. Each haat caters around 25 to 50 surrounding villages from where farmers do come and trade.

\section{Brand awareness for specific items sold at haats (\%):-}

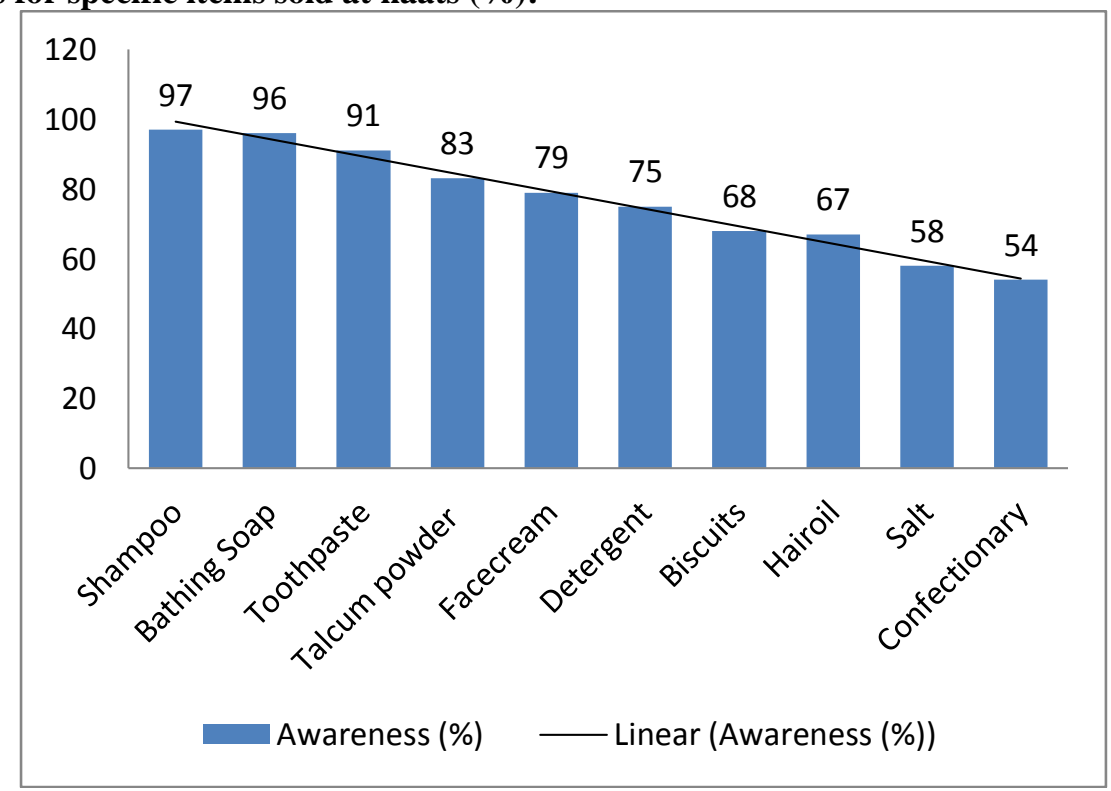

Source: Financial express Feb 9, 2011.

The above data indicates the awareness level of rural consumers. The brand awareness level plunge for confectionery and cosmetics, which implies rural people are less brand-conscious compared to the urban. Also, the rural consumers recognize the brand by the design and colour of package or product. Hence the brand recall is comparatively lower.

FMCG products preferred at haats:-

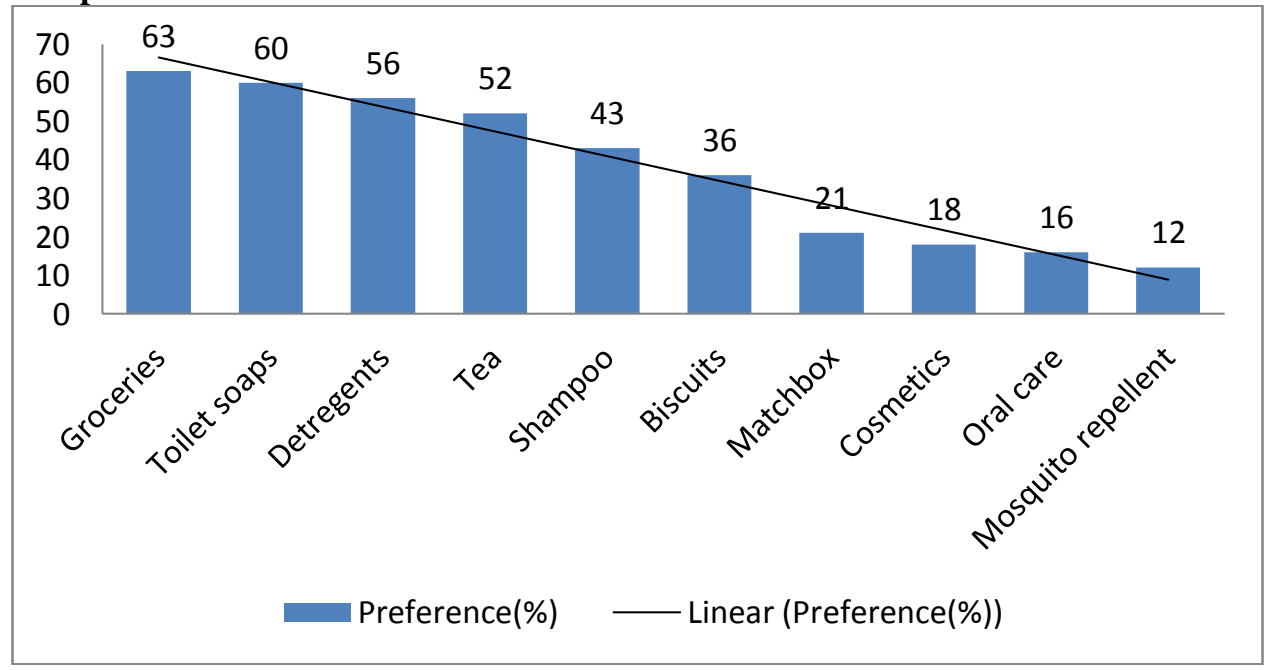

Source: Financial express Feb 9, 2011. 
Above data indicates the highest preference is for groceries followed by soap and detergents. The least preference is noted for health care, oral care and cosmetics. Unfortunately, the products which are sold least at haats are the ones which occupy maximum shelf space and sales in Organised retail outlets.

Sale of FMCG products per outlet on a haat day (Rs.):-

\begin{tabular}{|l|l|l|}
\hline $\begin{array}{l}\text { Leading states where haats are } \\
\text { Organised }\end{array}$ & Sale of Branded FMCG (Rs.) & $\begin{array}{l}\text { Total sales of FMCG (including } \\
\text { unbranded) (Rs.) }\end{array}$ \\
\hline Maharashtra & 2793 & 13196 \\
\hline Bihar & 3450 & 12490 \\
\hline Uttar Pradesh & 2864 & 7229 \\
\hline Orissa & 2730 & 5205 \\
\hline Andhra Pradesh & 339 & 1741 \\
\hline Madhya Pradesh & 421 & 4231 \\
\hline Tamil Nadu & 2971 & 8553 \\
\hline Average & 2224 & 7521 \\
\hline
\end{tabular}

Source: Financial express Feb 9, 2011

On a haat day, an average buyer spends around Rs. 40 on FMCG products. The spending varies from Rs 22 to Rs.60. The average sale of branded FMCG products is around $29.57 \%$ whereas in the case of the unbranded products it is $70.43 \%$. Hence from the above data, it is obvious that rural customers prefer items are cheaper to afford than going by quality and brand.

Comparison of consumption pattern of FMCG's both Rural and Urban Areas:-

\begin{tabular}{|l|l|l|l|}
\hline FMCG's & Urban & Rural & Total (\% of Rural HH) \\
\hline Shampoo & 66.3 & 35.2 & 44.2 \\
\hline Toothpaste & 82.2 & 44.9 & 55.6 \\
\hline
\end{tabular}

Source: NCAER Report, 2011.

The above data is an indication of the consumption pattern of rural consumers which clearly state the preference for FMCG's in both rural and urban markets.

\section{Review of Literature:-}

742 million people in India live in 6 lakhs plus villages. A lakh of these hold 50\% of India's rural population accounting for $60 \%$ of its wealth. Roughly 320 million of the populations residing in five lakh villages are not targeted customers for marketers, simply because it isn't viable to cater to them.

Ali Harris, Britannia's Brand Manager for Tiger Biscuits, says: "If I go to a shop in Mumbai, I will sell Rs 5,000 worth of stock and my cost to reach that outlet is next to nothing. If I need to reach an interior village, I would have to hire a van from the nearest town, and then probably sell Rs 50 worth of stock in the village."

According to a nationwide survey conducted by consultants McKinsey \& Co, of 593 rural districts, 248 are "deprived" and lack basic infrastructure like all-weather roads. Adil Zainulbhai, Managing Director, McKinsey \& Co, says: "Almost half of India's rural population does not have access to good roads and decent.

In a paper "The Retail buzz in Rural India" by A Aziz Ansari and Amir Ullah Khan, it says" the physical infrastructure investment is a form of 'complementary capital' that supports services necessary for the operation of productive private capital".

The paper also quotes the study on rural infrastructure by Jalan and Ravollion (2002) to establish a direct link between infrastructure and economic growth through extensive studies in rural China. As per their estimates, every 1 per cent increase in the road density per capita, the private consumption expenditure increased by 0.08 per cent in rural China.

According to an article on rural retail, The Hariyali Kisaan Bazaar, India's biggest rural retail chain by sales, sell agri-inputs, cattle feed, plastic furniture, FMCG products, and automobiles, besides services such as banking and 
crop insurance, which operates 230 stores across eight states(Haryana, Punjab, Uttar Pradesh, Rajasthan, Uttarakhand, Madhya Pradesh, Maharashtra and Andhra Pradesh), said it had seen a fall in rural demand in the past two to three months. The reason for the same is a drop-in price of potatoes, onions and some other vegetables, leading to low realization for farmers, and an increase in the cost of fertilizer.

The article mentioned above also throws light on issued faced by major retailers in rural markets due to infrastructure, distribution and fluctuating rural incomes, along with competition from local Kirana stores, which operate at much lower costs. In early 2010, Triveni Engineering shut its rural retail arm, Khushali Bazaar, after incurring a loss of Rs 19 crore in five years. ITC has not expanded its ChoupalSagaar business for the past few years. Godrej sold its Aadhaar rural retail business to the Future Group and the latter revamped it into a wholesale format. HariyaliKisan Bazaar had to shut at least 70 outlets over the past couple of years.

The article also mentioned a study by CII-Technopark on rural retail, the biggest bottleneck towards development in the rural markets is excessive dependence on agriculture and, consequently, on rainfall. There is an overall slowdown of GDP growth every time there is poor rainfall.

According to an article on "Rural India promises growth for retail", the experts are of the opinion that in rural markets, consumers are practical and price-sensitive, but they are more loyal even though they have varying income. According to an article on "Features of Indian rural market", it says "Study on buying behaviour of rural consumer indicates that rural retailers influence $35 \%$ of purchase decisions. Therefore, mere product availability can affect the decision of brand choice, volumes and market share".

According to an article on "Rural retail revolution: the rise of rural market" -The biggest challenge in rural retailing is to ensure product availability across the 638,000 villages, which are spread out over three million sq. km in India. The problem is further compounded by the geographical vastness of reaching the 12 million-strong Kirana stores in the country. The cost of distribution gets added when reachability becomes a major problem and is possible only through the channel of distributors and wholesalers.

In a paper "Prospects and problems of Indian rural markets," it says "Life in rural areas is still governed by customs and traditions and people do not easily adapt new practices. For example, even the rich and educated class of farmers does not wear jeans or branded shoes".

An article on "The Future, On Sale: The Indian Retail Market" has a report by the Indian Council for Research on International Economic Relations (ICRIER) which states that only 1.7 per cent of stores in the unorganized market close each year and that by 2013, unorganized retail businesses will still account for 85 per cent of the Indian retail market. Though businesses located near a newly opened organized retailer lost 23 per cent of their sales in the first year after that new business opened, ICRIER found that after five years, sales totals for unorganized businesses returned to their previous levels.

In an article on "Why Companies See Bright Prospects in Rural India" B.N. Garudachar, general manager, corporate communication and investor relations at Voltas quoted that Voltas group recognize rural India by certain characteristics," says, a Tata group company in air-conditioning and engineering services. "These are low population numbers, low median income, poor infrastructure [roads, electricity, communications], and agrarian rather than industrial activity. Such rural areas are within the sphere of influence of neighbouring cities and metros. This influence determines their aspiration levels and their viability as markets."

\section{Objectives of This Paper:-}

1. To analyze the challenges in retailing in rural India with special reference to Kirana shops.

2. To explore the issues faced by large organized retail stores in entering rural India.

\section{Analysis and Findings:-}

Major setbacks faced by retail giants in entering rural markets

No entry for foreign retailers to cities where the population is below 10 lakhs:-

As per the Indian government rule, these retail giants can't enter the rural markets since their population I much below the 10 lakhs margin. Hence small Kirana shop owners need not face stiff completion from these retail giants. 
Population density of Indian villages is much lesser compared to the cities:-

In Indian villages where the infrastructure and transportation are the major problems, big retail stores will have few customers accessing them. The population density makes it much more difficult for any marketing campaigns to attract these customers.

Rural customers already enjoy the personal touch and small credit facilities provided by the Kirana shops:In India business happens through relationships and especially in rural markets where the number of Kirana shops is few in a particular locality the villagers share a strong bonding with these shop owners. Also, the Kirana shop owners give small credit facilities which enable them to manage the expenses for that particular month. Big retail stores lack this.

\section{Frequency of purchase:-}

The main items which are purchased from the retail outlets include groceries, toiletries, detergents and hair and personal care. Most urban customers prefer shopping for a month since they don't have time. hence the volume of purchase is very high. Whereas the rural customers do buy in smaller quantities and frequently since their income varies on day to day basis.

\section{The low literacy rate in rural markets:-}

The low literacy levels in rural markets are another major cause to worry at, because of the marketing communication by retailers doesn't reach them in the way it is supposed to be. Print media becomes ineffective in such areas.

External and internal risk factors for the companies entering the Indian rural markets:-

Following tables present the risk elements need to be considered by any company willing to enter the rural markets of India. Grade A represents the high attention factors with some solutions while B grade represents the factors with exceptional solutions.

External risk factors for the companies entering in the rural markets of India:-

\begin{tabular}{|l|l|l|}
\hline Particulars & Category & Grade \\
\hline Less information about the markets and consumer behaviour & Controllable & A \\
\hline Unavailability of skilled local talent & Controllable & B \\
\hline Uneven demand & Non-controllable & A \\
\hline Imperfect local distribution channel & Controllable & A \\
\hline Pathetic infrastructure & Non controllable & B \\
\hline Scarce access to money market & Controllable & B \\
\hline Socio cultural mosaic & Non controllable & A \\
\hline Lack of adequate logistic support & Controllable & A \\
\hline Legal hassles & Non-controllable & A \\
\hline Confrontation of local business communities & Non controllable & B \\
\hline Paradigm shifts in consumer behaviour & Non-controllable & A \\
\hline
\end{tabular}

Internal risk factors for the companies entering in the rural markets of India:-

\begin{tabular}{|l|l|l|}
\hline Particulars & Category & Grade \\
\hline Less experience of the rural areas & Non-controllable & B \\
\hline Organization structure and culture & Controllable & A \\
\hline Salesforce bottlenecks & Controllable & A \\
\hline Doubt about the feasibility of the rural market conditions & Non-controllable & B \\
\hline Large window period & Non-controllable & B \\
\hline Huge investment & Non-controllable & A \\
\hline Leadership qualities and motivational ability of the management & Controllable & A \\
\hline Local competition & Non-controllable & A \\
\hline Imitated goods & Non-controllable & B \\
\hline
\end{tabular}

Source: Article on Fortune Rural India An Overview by Prof. Preeti M. Kulkarni, Navjeevan Institute of Management, Pune. 


\section{Conclusion:-}

It is obvious that Kirana stores are growing and trying to adapt to the market conditions by offering wider product ranges in FMCG and better services like free home delivery, better credit facilities, and payment options. Just to add to the credits of Kirana stores, they provide employment for over 39.5 million people in India. Even though there are many issues connected with the basic amenities in rural markets Kirana stores remain the most preferred shopping destination for the villagers in the neighbourhood. It is important to mention here that the Kirana stores still rule the major retail market in India even today with lots of development in technology and modern means of marketing and services by the larger retail stores. With all these, they might be able to continue their presence in $\$ 450$ billion industry and withstand the stiff completion from the large retail stores.

\section{References:-}

1. Indian streams research journal- Volume - I, ISSUE - IV May 2011: Management.

2. Ali Harris, Britannia's Brand Manager for Tiger Biscuits,2007, "Salvation on sachets" published in Mobility Techzone (online), January 29, 2007, Available at http://www.mobilitytechzone.com/news/2007/01/29/2287837.htm.

3. Adil Zainulbhai, Managing Director, McKinsey \& Co, 2007, "Salvation on sachets" published in Mobility Techzone (online), January 29, Available at http://www.mobilitytechzone.com/news/2007/01/29/2287837.htm.

4. A Aziz Ansari and Amir Ullah Khan, "The Retail buzz in Rural India”,www.bmaindia.com(online), Available athttp://www.bmaindia.com/pdfs/research/The\%20Retail\%20buzz\%20in\%20Rural\%20India.pdf?phpMyAdmin $=51122 \mathrm{~b} 35 \mathrm{e} 307 \mathrm{c} 1 \mathrm{cce} 3151662 \mathrm{fbdab} 631$.

5. Ajay Modi, "Rural retail sees falls in demand",2012, Business standard newspaper, December 17, 2012, Available at http://www.business-standard.com/india/news/rural-retail-sees-fall-in-demand/461931/.

6. Rupali Mukherjee, "Rural India promises growth for retail",2009, Times of India newspaper, April 8, 2009, Available at http://timesofindia.indiatimes.com/business/india-business/Rural-India-promises-growth-forretail/articleshow/4371528.cms.

7. Deepanshu Goel, "Features of Indian Rural markets",2007, Education SAP, Retail, CS guide, June 21, 2007, Available at http://edu.goelji.com/retail/rural-retailing/features-of-indian-rural-markets.html.

8. Ashish Gupta, "Rural retail revolution: the rise of the rural market",2011 South Asian Journal of Marketing \& Management Research Volume 1, Issue 3 (December 2011).

9. V.V Devi Prasad Kotni, "Prospects and problems of Indian rural markets", 2012, ZENITH International Journal of Business Economics \& Management Research Vol.2 Issue 3, March 2012, ISSN 22498826.

10. Taylor Salisbury, "South Asia Monitor: The Future, On Sale: The Indian Retail Market", 2010, Centre for strategic and international studies, January 6, 2010, Available at http://csis.org/publication/south-asia-monitorfuture-sale-indian-retail-market-january-6-2010.

11. B.N. Garudachar, General manager, corporate communication and investor relations at Voltas, "Why Companies See Bright Prospects in Rural India",2009, India Knowledge @Wharton, June 18, 2009, Available at http://knowledge. wharton.upenn.edu/india/article.cfm?articleid=4386. 